\title{
15 病院物流における医療業界連携のあり方に関する研究
}

\section{酒 井 順 哉（名城大都市情報学部人間情報処理研究室）}

今日，診療業務の円滑な連携と医療事務の合理化を 因るため，オーダリングンステムなどの病院情報シス テムを導入する病院が増えてきた，近年では，病院経 営を重視する意味から医療材料の在庫軽減や効率的な 運用を目指した院内物流システムや医療材料供給の外 注方式 (SPD: Supply Processing and Distribution) が病院に導入されるようになった. 院内物流システム pSPD は, 院内部門間の医療材料の受発注作業を効 率化することに役だったが，病院と医療材料を納品す る業者間の受発注業務には大きな改善はもたらしてい ない。

この原因として，受発注業務で取り扱われる各種伝 票書式が病院と業者で統一されていないことが挙げら れる. また，院内物流システムや SPD の導入に伴っ てインホスピタルマーキング (inhospital marking) で作成されたバーコードが対外的に活用できないこと に加兄，納品時に医療材料へのラベル貼り作業が付加
したことも受発注業務を煩雑にしている。これらの状 況により，医療材料の迅速な納品処理やラベル貼り・ 指定伝票作成に伴ら人件費の削減は未だ改善されてい ない。

このような現状に括いて, 今後, さらに病院では院 内物流システムや SPD が導入されることが予想され る. 一方，医療材料の製品管理や事務作業の合理化を 目的にソースマーキング (source marking) でバーュ 一ド表示を導入した製造メーカーもあるが，未だこー ドの標準化は図られて拈らず, 医薬品業界の事例が示 すよらに複数の物流ネットワークが錯綜し, 適正で効 率のよい物流システムを阻害することが勲念される.

これらの問題を解決するためには，病院および業者 の受発注業務で扱われる伝票書式の統一化とともに, 医療材料の商品識別コードの標準化が必要である. 今 回，病院と医療業界が物流の改善に向かって行うべき 具体策について検討したのでここに報告する.

\section{ME 機器の中央化に向かって一注入ポンプに関してー}

富安重雄, 大島博幸（東京医科歯科大病院材料部）

本院の $\mathrm{ME}$ 機器中央化対象機器は, 人工呼吸器, 注 入ポンプ，超音波ネブライザー，低王持続吸引器を主 に, 他に新規購入する心電計や除紐動器の中央化も実 施している．前回の報告の中では人工呼吸器の中央化 終了を報告した，今回は，治療機器の中で最も使用頻 度の高い注入ポンプの中央化，それに伴った保守管理 について平成 8 年 3 月までの結果を報告する. 現在, 中央化台数は輸夜ポンプ 106 台, シリンジポンプ63台 である，過去取り扱った台数は各 134 台：76台であっ た. その中で今回, 廃充更新対象とした台数は各 15 台：13台で購入年度の古い物は70年代があり，主に82 年から86年購入の物である。それらは明らかに旧タイ プの物あるいは高額修理にて修理保留にしていた物の みである、一般病棟から中央化する際，点検整備し使 用可能であると判定し，整備した台数は各70台：35台 であった：その中で本院に扔いてバッテリー点検によ るバッテリーの回復が多数あり，その他特に，バッテ
リー・筐体等交換修理した台数が各29台：3台. 業者 修理にてバッテリー・プリント基板・筐体等交換した 台数が各 9 台：2台であり, 修理により計38台：5台 が使用可能になった. 過去, 何らかの異常状態で一般 病棟に保管され，使用待ちされていた台数は各53台： 18台であり，中央化によりトラブル等が末然に防げた ものと考えられる。また，中央化を含めた業者修理件 数は94年度 8 件で平均費用は $¥ 67,393 ， ま た ， 95$ 年度 31 件その平均費用は $¥ 46,336$ となり，中央化の関係上 業者修理件数は増加した.ささに，91年度から95年度 までの延べ点検整備台数は 840 台であり，94年度が 234 件, 中央化を開始した 95 年度が 367 件と增加し, 材料部に执いての注入ポンプ取り扱い時間の比重は增 加したことになる．上記を含めて昨年までのコストの 比較をし報告する.

最後に, 病院で $\mathrm{ME}$ 機器のセンター化を進めるには, マンパワーである人的資源が絶対必要となる. 